We thank the statistical office of the municipality of Fredericia for providing the population data and Mrs Rita Moreau for secretarial help. The plasma $C$ peptide analyses were done by the Hagedorn Research Laboratory and lipoprotein analyses by the lipid research laboratory of Allborg Hospital. We also thank Drs Birgit Kvinesdal and Jens Rokkedal Nielsen for coding the electrocardiograms. The work was supported by the Danish Diabetes Association, the Danish Heart Association, and the Vejle County Research Foundation.

1 Mogensen CE, Chachati A, Christensen CK, et al. Microalbuminuria: an early marker of renal involvement in diabetes. Uremia Investigations 1985-6;9: $85-95$

2 Mogensen CE. Microalbuminuria predicts clinical proteinuria and early mortality in maturity-onset diabetes. $N$ Engl $\mathcal{G}$ Med 1984;310:356-60.

3 Jarrett RJ, Viberti CG, Argyropoulos A, et al. Microalbuminuria predicts mortality in non-insulin-dependent diabetes. Diabetic Med 1984;1:17-9.

4 Schmitz A, Vaeth M. Microalbuminuria: a major risk factor in non-insulin dependent diabetes. A 10 -year follow-up study of 503 patients. Diabetic Med 1988;5:126-34.

5 Mattock MB, Keen H, Viberti GC, et al. Coronary heart disease and urinary albumin excretion rate in type 2 (non-insulin-dependent) diabetic patients. Diabetologia 1988;31:82-7.

6 Mogensen CE, Christensen CK. Predicting diabetic nephropathy in insulindependent patients. $N$ Engl $\mathcal{F}$ Med 1984;311:89-93.

7 Viberti G. Etiology and prognostic significance of albuminuria in diabetes. Diabetes Care 1988;11:840-5.

8 Mogensen CE, Schmitz A, Christensen CK. Comparative renal pathophysiology relevant to IDDM and NIDDM patients. Diabetes/Metabolism Review 1988;4:453-83.

9 Damsgaard EM, Mogensen CE. Microalbuminuria in elderly hyperglycaemic patients and controls. Diabetic Med 1986;3:430-5.

10 Yudkin JS, Forrest RD, Jackson CA. Microalbuminuria as predictor of vascular disease in non-diabetic subjects. Lancet 1988;ii:530-3.

11 Damsgaard EM, Frøland A, Green A, Hauge M. An alternative sampling approach to the study of diabetes prevalence. Scand f Soc Med 1984;12: $115-20$

12 Faber $\mathrm{OK}$, Nielsen $\mathrm{OH}$, Beck-Nielsen $\mathrm{H}$, et al. Beta-cell secretion as a measure of insulin dependency in diabetic patients [Abstract]. Acta Endocrinol 1984; Suppl 106:2.
13 Schmidt FH. Enzymatische Teste zur Schnell-Diagnose. In: Beringer A, ed. International Donau-symposium diabetes melitus 3. Vienna: Springer Verlag, 1973:567-8.

14 Dyerberg J, Meinertz $\mathrm{H}$. Comparison of determination of plasma lipoprotein concentration by ultracentrifugation and electrophoresis. In: Peeters $\mathrm{H}$, ed. Proteides of the biological fuids (proceedings of the 25th colloquium). New York: Pergamon Press, 1978:419-21.

15 Heding LG. Radioimmunological determination of human C-peptide in serum. Diabetologia 1975;11:541-8.

16 Miles DW, Mogensen CE, Gundersen HJG. Radioimmunoassay for urinary albumin, using a single antibody. Scand f Clin Lab Invest 1970;26:5-11.

17 Rose GA, Blackburn H. Cardiovascular survey methods. Geneva: World Health Organisation, 1968:137-45.

18 Ellestad MH. Stress testing principles and practice. Philadelphia: F A Davis, $1975: 15$

19 Kusumi RK, Grover PJ, Kunin CM. Rapid detection of pyuria by leucocyte esterase activity. JAMA $1981 ; 245: 1653-5$.

20 Cox DR. Regression models and life tables. Journal of the Royal Statistical Society 1972;B34:187-220.

21 Kannel WB, Stampfer MJ, Castelli WP, Verter J. The prognostic significance of proteinuria: the Framingham study. Am Heart 7 1984;108:1347-52.

22 Castelli WP, Garrison RJ, Wilson PWF, et al. Incidence of coronary hear disease and lipoprotein cholesterol levels. FAMA 1986;256:2835-8.

23 Gordon T, Castelli WP, Hjortland MC, et al. High density lipoproteins as a protective factor against coronary heart disease: the Framingham study. Am F Med 1977;62:707-14.

24 Pyörälä $K$, Laakso $M$, Uusitupa $M$. Diabetes and atherosclerosis: an epidemiological view. Diabetes/Metabolism Reviews. 1987;3:436-524.

25 Eschwege E, Richard JL, Thibault N, et al. Coronary heart disease mortality in relation with diabetes, blood glucose and plasma insulin levels. The Paris relation with diabetes, blood glucose and plasma insulin levels. The Par
prospective study, ten years later. Horm Metab Res 1985;suppl 15:41-6.

26 Pyörälä K, Savolainen E, Kaukola S, Haapakoski J. Plasma insulin as coronary yörälä $\mathrm{K}$, Savolainen $\mathrm{E}$, Kaukola $\mathrm{S}$, Haapakoski J. Plasma insulin as coronary
heart disease risk factor: relationship to other risk factor and predictive value during $91 / 2$-year follow-up of the Helsinki policemen study population. Acta Med Scand 1985; suppl 701:38-52.

27 Welborn TA, Wearne $\mathrm{K}$. Coronary heart disease incidence and cardiovascular mortality in Busselton with reference to glucose and insulin concentration. Diabetes Care 1979;2:154-60.

28 Shearman CP, Gosling P. Microalbuminuria and vascular permeability. Lance 1988;ii:906-7.

(Accepted 27 November 1989)
Department of Medicine and Retrovirus Research Group, Northwick Park Hospital and Clinical Research Centre, Harrow HA1 3UJ

J K Cruickshank, MD, senior registrar

J H Richardson, PHD, research fellow

A L Newell, BSC, research officer

P Rudge, FRCP, consultant neurologist

A G Dalgleish, FRACP, head of group

Faculty of Medicine, University of West Indies,

Kingston 7, Jamaica

O St C Morgan, FRCP, professor

J Knight, medical student

Medical School,

University of Oxford,

Oxford

J Porter, medical student

P Klenerman, medical

student

Correspondence to: $\mathrm{Dr}$ Cruickshank.

Br Med f 1990;300:300-4

\title{
Screening for prolonged incubation of HTLV-I infection in British and Jamaican relatives of British patients with tropical spastic paraparesis
}

J K Cruickshank, J H Richardson, O St C Morgan, J Porter, P Klenerman, J Knight, A L Newell, P Rudge, A G Dalgleish

\section{Abstract}

Objective-To compare the prevalence of antibody to and proviral DNA of the retrovirus HTLV$I$ in relatives of 11 British patients with tropical spastic paraparesis who had migrated from Jamaica before they developed symptoms, and to examine factors possibly related to transmission of HTLV-I.

Design-Migrant, family study. Antibody state was determined by several methods and confirmed by western blotting; the polymerase chain reaction was used to detect proviral DNA.

Setting-Britain and Jamaica.

Subjects-All available first degree relatives: those born and still resident in Jamaica (group 1); those born in Jamaica who migrated to Britain (group 2 ); and index patients' children who were born and resident in Britain (group 3). All had been breast fed and none had had blood transfusions.

Results - Of the 66 living relatives, 60 were traced. Seroprevalence among those born in Jamaica (irrespective of current residence) was $22 \%(10 / 46$; 95\% confidence limits 9 to $34 \%$ ) compared with zero among British born offspring (0/14) and was higher in group 2 at $33 \%(7 / 21 ; 12$ to $55 \%)$ than in group 1 at $12 \%(3 / 25 ; 0$ to $25 \%)$. (Patients in group 1 had the greatest mean age.) Proviral DNA was not detected in any subject negative for HTLV-I antibody, making prolonged viral incubation in those negative for the antibody unlikely.

Conclusion-In this sample factors related to place of birth and early residence were more important in transmission of HTLV-I than maternal or age effects. In areas with a low to moderate prevalence policies of preventing mothers who are carriers of the virus from breast feeding would be premature.

\section{Introduction}

The human $\mathrm{T}$ cell leukaemia lymphoma virus type I (HTLV-I) has been aetiologically related to the adult T cell leukaemia lymphoma syndrome and, more recently, to tropical spastic paraparesis..$^{2-4}$ Both diseases occur primarily in the major areas where HTLV-I is endemic - south western Japan and the Caribbeanbut also develop in migrants from these regions. The cumulative lifetime risk of developing either disease in otherwise healthy people with antibodies against HTLV-I has been estimated at between $2 \%$ and $7 \%$ and rises with age. ${ }^{9-11}$ Oddly, the risk of adult $\mathrm{T}$ cell leukaemia lymphoma is consistently greater in male carriers of HTLV-I than in female carriers, while that of tropical spastic paraparesis is greater in females and reflects the sex ratio of seroprevalence of HTLV-I in the population.

Known routes of HTLV-I transmission include transfusion with infected cellular blood products, sexual activity, and perinatal transmission from mother to child. ${ }^{12-14}$ Whether breast feeding or other perinatal routes are responsible is uncertain but of considerable 
importance for public health. There is familial aggregation of HTLV-I infection and poor housing, and proximity to courses of water may increase seroprevalence in endemic areas. ${ }^{1415}$ As the incidence of HTLV-I seropositivity rises with age it is not clear whether there is a prolonged incubation period of the virus in people negative for the antibody. The generally late onset of HTLV-I associated disease is, however, consistent with a prolonged incubation time between seroconversion and development of disease. These questions can be examined by studying migrants from areas of high prevalence to areas of low prevalence.

Migrant studies also help to dissect out the effects of lifestyle, climate, and other measurable variations (such as exposure to infection) on disease. ${ }^{16}$ Our previous studies of West Indian born migrants who developed tropical spastic paraparesis in Britain and had antibodies to HTLV-I suggested an average incubation period of 18 years, ranging up to 34 years, assuming that the patients were carriers of HTLV-I at the time of migration. ${ }^{78}$

Family studies also provide a focus for analysing transmission and information critical to developing strategies to prevent or interrupt viral transmission. In this study we analysed familial aggregation of HTLV-I infection in all first degree relatives of our Jamaican born patients with tropical spastic paraparesis to seek clues to methods of HTLV-I transmission. We aimed at establishing the prevalence of HTLV-I antibodies and of integrated retroviral DNA in these people. We used the polymerase chain reaction, a highly sensitive method for detecting proviral DNA, to test whether seronegative family members might have viral genome sequestered in peripheral blood leucocytes without detectable antibody production.

\section{Patients and methods}

Our primary hypothesis was that there would be family clustering of HTLV-I infection. If transmission of HTLV-I occurs primarily in endemic areas such as Jamaica and to a much lesser degree in a temperate climate such as Britain HTLV-I antibodies would be most prevalent in relatives born and living in Jamaica (group 1), present at intermediate rates in relatives born in Jamaica and living in Britain (group 2), and minimal in offspring born in Britain (group 3). If there was excess family transmission the prevalence in each group would be greater than that in the comparable general population of the same age.

Clinical, neuroradiological, and serological details of 21 index patients with tropical spastic paraparesis have been described previously ${ }^{78}$; the 19 women and two men, all postitive for HTLV-I antibody, had been born in the West Indies and migrated to Britain an average of 29 years previously. Their mean (SD) age was $56(6)$ years and duration of disease 9 (5) years when investigated. We included only the first 11 Jamaican born index patients of the series in this study because they were the only subjects from Jamaica when the sampling for the study was carried out, there were detailed data on the prevalence of HTLV-I infection in Jamaica, ${ }^{10}$ and relatives of other patients from the eastern Caribbean islands were precluded from inclusion because of limitations on travel. Rough estimates of the likely prevalence of the antibody to HTLV-I based on Jamaican population studies were $15 \%$ for the relatives in group $1,5-8 \%$ for the somewhat younger relatives in group 2 , and $1-3 \%$ for the offspring in group 3 .

The Jamaican born index patients did not differ in basic characteristics from those born in the eastern Caribbean (table I), had also spent about half their lives in Britain, and had the same mean duration of disease. Their degree of disability ranged from minor unilateral leg weakness (but bilateral spasticity) to complete
TABLE I-Details of 11 index patients with tropical spastic paraparesis

\begin{tabular}{ccccc}
\hline Sex & $\begin{array}{c}\text { Age } \\
\text { (years) }\end{array}$ & $\begin{array}{c}\text { Time in } \\
\text { Britain } \\
\text { (years) }\end{array}$ & $\begin{array}{c}\text { Age at onset } \\
\text { of symptoms } \\
\text { (years) }\end{array}$ & $\begin{array}{c}\text { Duration of } \\
\text { disease } \\
\text { (years) }\end{array}$ \\
\hline F & 52 & 26 & 47 & 4 \\
M & 53 & 29 & 49 & 4 \\
$F$ & 55 & 30 & 51 & 4 \\
$F$ & 53 & 26 & 47 & 6 \\
$F$ & 61 & 23 & 54 & 7 \\
$F$ & 48 & 26 & 39 & 9 \\
$F$ & 53 & 25 & 42 & 9 \\
$F$ & 49 & 29 & 37 & 12 \\
F & 65 & 35 & 52 & 13 \\
F & 48 & 26 & 33 & 15 \\
F & 52 & 32 & 36 & 16 \\
\hline Mean (SE) & $53 \cdot 5(1 \cdot 7)$ & $27 \cdot 9(1 \cdot 0)$ & $44 \cdot 3(2 \cdot 2)$ & $9 \cdot 0(1 \cdot 3)$ \\
\hline
\end{tabular}

paraplegia and restriction to a wheelchair. In contrast to the symptoms of multiple sclerosis cranial nerve signs were absent and arm involvement rare and minimal.

Details of all first degree relatives (parents, siblings, and children) and spouses or current and recent partners were obtained, with informed consent, from the index patients. The patients contacted their relatives in both Britain and Jamaica and asked permission for us to visit them. Relatives were asked to complete a questionnaire for analysis of risk factors, which included giving information on places and duration of residence since birth, family size, age, history of breast feeding, history of blood transfusion, and number and duration of spouses or partners. Efforts were made to trace all known living relatives, each of whom was visited in his or her home.

With the patients' permission $30 \mathrm{ml}$ of whole blood was taken and mixed with EDTA for subsequent DNA extraction and serum was obtained from $10 \mathrm{ml}$ blood. Whole blood and serum samples were stored at $-20^{\circ} \mathrm{C}$ and then at $-70^{\circ} \mathrm{C}$ until required.

\section{SEROLOGY}

The serological methods used have been described previously. ${ }^{17}{ }^{18}$ Serum samples were considered positive for HTLV-I antibody only if positive results were obtained by using at least two of the following methods agglutination (Serodia, Tokyo, Japan), immunofluorescence, enzyme linked immunosorbent assay (ELISA) (DuPont, Wilmington, Delaware, United States), and antibody dependent cell mediated cytotoxicity tests. Positive results were then confirmed by western blot analysis.

\section{DNA ANALYSIS}

DNA was extracted from whole frozen blood. ${ }^{19}$ For the polymerase chain reaction each DNA sample was tested within two sets of primers specific for the gag and $\mathrm{X}$ regions of the HTLV-I genome. The gag primers were 5'GTCAGACCTGGACCCCCAAAGAC3 and 3'GTCTCGGTCTCCTTCTACGGGAG5', which amplified the region from $1795 \mathrm{bp}$ to $2030 \mathrm{bp}$. X region primers were 5'CCTTCTCAGCCCCTTGTCTCCAC3 and 3'GCGACGGCTAGTGCTACGCAAAG5', which amplified the region from $6824 \mathrm{bp}$ to $7066 \mathrm{bp}$. Oligonucleotide probes used to detect the amplified products were 5'CCCCAAATCAGCCGTGCTTC3' (for the gag region) and 5'TACTCAGCGGTCTGCTTTTCC 3 (for the $\mathrm{X}$ region).

Reactions were performed in a $50 \mu \mathrm{l}$ volume using $1 \mu \mathrm{g}$ of DNA, 1 unit of Taq polymerase (Perkin Elmer Cetus, Norwalk, Connecticut, United States), and 0.5 $\mu \mathrm{g}$ of each primer. The reaction buffer was potassium chloride $50 \mathrm{mmol} / \mathrm{l}$, magnesium chloride $1.5 \mathrm{mmol} / \mathrm{l}$, deoxynucleoside triphosphate $200 \mu \mathrm{mol} / \mathrm{l}$, TRIS HCl buffer $(\mathrm{pH} 8.3) 10 \mathrm{mmol} / 1$, and $0.01 \%$ gelatin. Samples were denatured for 10 minutes at $95^{\circ} \mathrm{C}$ and then given 30 and 45 cycles of amplification (at $60^{\circ} \mathrm{C}$ for $0 \cdot 1 \mathrm{~min}$, at 
$72^{\circ} \mathrm{C}$ for $0.5 \mathrm{~min}$, and at $93^{\circ} \mathrm{C}$ for $0.1 \mathrm{~min}$ ). An aliquot of $10 \mu \mathrm{l}$ of the reaction products was analysed by electrophoresis in $2.5 \%$ agarose and transferred to a Zetaprobe membrane (Bio-Rad Laboratories, Richmond, California, United States) in sodium hydroxide $0.4 \mathrm{~mol} / \mathrm{l}$. Filters were incubated for 1 hour at $50^{\circ} \mathrm{C}$ in 6 strength standard saline citrate, $1 \%$ sodium dodecyl sulphate, and $0.5 \%$ dried skimmed milk and then for two hours in the same solution containing $5 \mu \mathrm{g} / \mathrm{l}$ of oligonucleotide probe end labelled with phosphorus32 and T4 kinase to a specific activity of $5 \times 10^{8} \mathrm{dpm} /$ $\mu \mathrm{g}$. Filters were washed in 6 strength standard saline citrate with $1 \%$ sodium dodecyl sulphate for 10 minutes at room temperature and then 10 minutes at $50^{\circ} \mathrm{C}$ and underwent autoradiography for $0 \cdot 5-48$ hours at $-70^{\circ} \mathrm{C}$.

\section{Results}

The 11 Jamaican born patients with tropical spastic paraparesis had 66 living first degree relatives and spouses distributed between Jamaica and Britain. Five other relatives lived in the United States or Canada and were not contacted. Of 27 relatives in group 1, 25 were seen; of 24 in group 2, 21 were seen; and of 15 in group 3,14 were seen. Thus the total response rate was 60 of

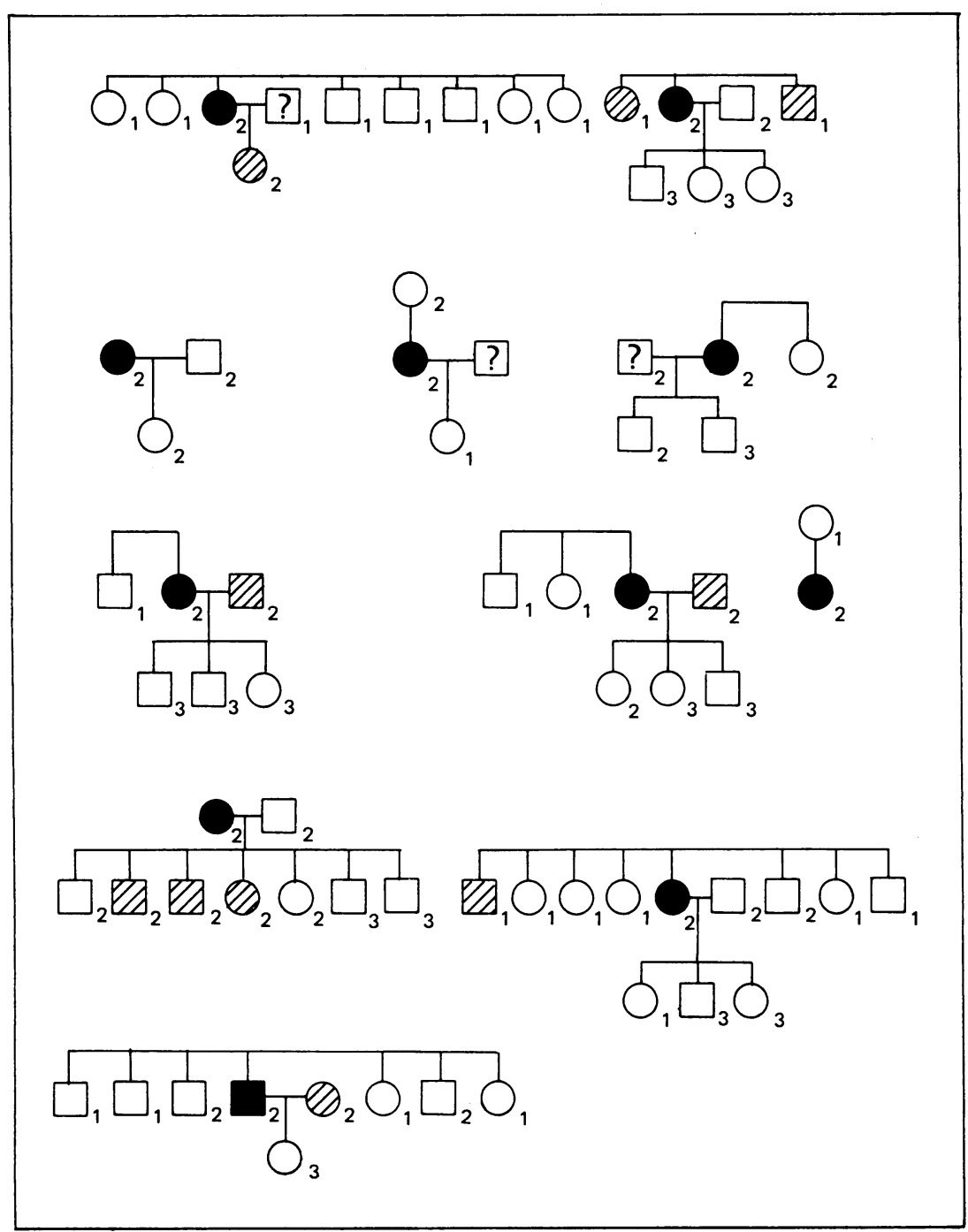

$\begin{array}{ll}\text { Male Female } \\ \begin{array}{l}\text { Index patient with tropical } \\ \text { spastic paraparesis }\end{array} \\ \text { Carrier of HTLV-I } & \text { Origin and residence of relatives: } \\ \text { Non-carrier of HTLV-I } & 1=\text { Born and living in Jamaica } \\ \text { ? HTLV-I state unknown } & 3=\text { Born in Jamaica, living in United Kingdom }\end{array}$

Family trees of 11 index patients with tropical spastic paraparesis
TABLE II-Living first degree relatives and spouses of 11 famaican born patients with tropical spastic paraparesis

\begin{tabular}{lccc}
\hline & Group 1 & Group 2 & Group 3 \\
\hline Mothers & 1 & 1 & \\
Siblings & 22 & 4 & 14 \\
Children & 2 & 9 & \\
Spouses & 25 & 21 & 14 \\
\hline Total & $51(3 \cdot 8)$ & $46 \cdot 2(4 \cdot 4)$ & $20 \cdot 2(3 \cdot 2)$ \\
\hline Mean (SE) age (years) & & & \\
\hline
\end{tabular}

^Includes one wife.

$66(91 \%)$ relatives; of the seven spouses or partners only one was a woman (table II).

Some relatives who were living in Britain (groups 2 and 3) had returned to Jamaica for short visits, the maximum number of visits being four and the maximum length of stay two months. The mean age of relatives born and living in Jamaica (group 1) was similar to that of the index patients; relatives in group 2 were some five years younger and those in group 3 were a generation younger (table II).

All 60 relatives reported having been breast fed as infants and none had had a blood transfusion. The breast feeding history of offspring was confirmed by the index patients.

\section{ANTIBODY TITRES}

Geometric mean antibody titres and ranges for the IgG enzyme linked immunoassay and the agglutination method (for all antibody classes) of the seropositive relatives were lower at 1:650 (range 1:64-1:1024) and 1:6800 (1:612-1:10000) respectively, compared with $1: 2825(1: 200-1: 6000)(\mathrm{p}<0.01)$ and $1: 46000(1: 10000$ $1: 100000)(\mathrm{p}<0.01)$ in the index patients. All seropositive relatives had positive results by at least three methods. A few serum samples that gave weakly positive results on immunofluorescence staining or atypical bands on western blotting but failed to give positive results in the other assays were classified as negative. The figure shows the individual family trees; family size was not associated with transmission of HTLV-I.

Table III gives the prevalence and age distribution of antibodies to HTLV-I in the three groups of relatives. Only three of $25(12 \%)$ relatives in group 1 , but seven of $21(33 \%)$ in group 2, were positive for HTLV-I antibody compared with none of the 14 offspring in group 3. These differences among the groups were significant $\left(\chi^{2}=7 \cdot 39 ; \mathrm{df}=2 ; \mathrm{p}<0 \cdot 02\right)$. The seropositive relatives were three siblings and three spouses (two men and the one woman) in groups 1 and 2 and four children in group 2 . Thus of the 23 children, four of nine born in Jamaica compared with none of 14 born in Britain were seropositive $(p=0.034$, Fisher's exact test). Of 38 immediate family members of the same Jamaican born generation (27 siblings and 11 index cases), 14 (37\%; 95\% confidence interval 21 to $53 \%)$ were positive for HTLV-I antibody (see figure). Neither of the two mothers of the index patients was positive. The total prevalence of seropositivity for all relatives and spouses born in Jamaica was 10/46 (22\%; 9 to $34 \%$ ).

\section{CONFIRMATION OF SEROLOGY BY THE POLYMERASE} CHAIN REACTION

The polymerase chain reaction for amplifying proviral DNA was used to test whether HTLV-I infection might occur in some people without an antibody response (table IV). After amplification viral DNA could be detected in all of the patients with tropical spastic paraparesis and all seven seropositive relatives tested but not in any of the 37 seronegative relatives 
TABLE III-Age specific prevalence of HTLV-I antibody in first degree relatives and spouses of 11 patients with tropical spastic paraparesis

\begin{tabular}{|c|c|c|c|c|c|c|c|}
\hline & \multicolumn{7}{|c|}{ Age (years) } \\
\hline & $10-19$ & -29 & -39 & -49 & -59 & $\geqslant 60$ & Total $(\%, 95 \%$ confidence interval $)$ \\
\hline Group 1 & & $0 / 1$ & $0 / 3$ & $1 / 7$ & $1 / 6$ & $1 / 8$ & $3 / 25(12,0$ to 25$)\}$ \\
\hline Group 2 & & $1 / 2$ & $3 / 6$ & $0 / 2$ & $2 / 7$ & $1 / 4$ & $7 / 21(33,12$ to 54$)\}^{10 / 46(22,9 \text { to } 34)}$ \\
\hline Group 3 & $0 / 5$ & $0 / 8$ & $0 / 1$ & & & & $0 / 14$ \\
\hline Total & $0 / 5$ & $1 / 11$ & $3 / 10$ & $1 / 9$ & $3 / 13$ & $2 / 12$ & $10 / 60$ \\
\hline
\end{tabular}

TABLE IV-Analysis by polymerase chain reaction of DNA from patients with tropical spastic paraparesis and their relatives. Figures in parentheses are numbers positive for HTLV-I DNA out of numbers tested

\begin{tabular}{lcc}
\hline Relatives & $\begin{array}{c}\text { No positive for HTLV-I } \\
\text { antibody }\end{array}$ & $\begin{array}{c}\text { No negative for HTLV-I } \\
\text { antibody }\end{array}$ \\
\hline Parents or siblings & $3(3 / 3)$ & $25(0 / 20)$ \\
Spouses & $3(1 / 1)$ & $4(0 / 2)$ \\
Children & $4(3 / 3)$ & $21(0 / 15)$ \\
\hline
\end{tabular}

^All mothers were positive for HTLV-I antibody.

examined, even with the method being able to detect 10 viral copies per $10^{5}$ leucocytes. ${ }^{19 \mathrm{a}}$ In particular, all 14 of the children born and living in Britain were confirmed as being negative for HTLV-I DNA by the polymerase chain reaction.

\section{Discussion}

This study has shown that the seroprevalence of HTLV-I of $22 \%(10 / 46)$ in the Jamaican born relatives of 11 patients with tropical spastic paraparesis (groups 1 and 2) was clearly higher than that of $0 \%$ in the 14 British born offspring (group 3), particularly as four of the nine Jamaican born children were seropositive $(p=$ $0 \cdot 03$ ). In all subjects tested the carrier state was confirmed by the polymerase chain reaction analysis of relatives' DNA, and no subject was positive for HTLV-I DNA and negative for HTLV-I antibody.

The $95 \%$ confidence interval ( 9 to $34 \%$ ) for the total prevalence of HTLV-I antibody in Jamaican born people overlaps with the 5 to $15 \%$ seroprevalence found in community studies of this age group in Jamaica. ${ }^{10}$ Thus, from this sample size, this rate would not confirm an excess prevalence in families of index patients with tropical spastic paraparesis compared with the general population in Jamaica. Immediate family clustering in the same generation, however, is clearly shown by including only the index patients and siblings in the prevalence $(37 \% ; 21$ to $53 \%)$ and excluding spouses, who were not exposed to family influences in childhood. Interestingly, the spouses, who were also all Jamaican born, showed a similar rate (3/7). No data for an adequate population sample of Jamaican born migrants in Britain are available, but in a small community study in north west London only two of $81(2 \%)$ randomly sampled Afro-Caribbean subjects (not just from Jamaica) aged 50-69 years were seropositive (JKC and ALN, unpublished data). If this $2 \%$ is representative then the family aggregation of HTLV-I in 7/21 (33\%) of relatives born in Jamaica and living in Britain is highly significant, but evidence from larger populations and numbers of families is needed for confirmation.

The incubation period from infection to becoming positive for HTLV-I antibody has to be distinguished from that between being positive for the antibody and development of clinical disease. Two main possibilities exist: firstly, that HTLV-I infection is acquired only in endemic regions, in which case the incubation period of tropical spastic paraparesis in our patients is long and the prevalence of seropositivity would be higher in relatives remaining in the Caribbean compared with those who emigrated (provided acquisition continued in those born and living in Jamaica after the time of emigration of the others). Our data do not support this; if anything, the Jamaican relatives resident in Britain had a higher rate of seropositivity (33\%) than relatives still in Jamaica (12\%), who were slightly but significantly older (table I), indicating that age does not account for these differences. A second, more likely, possibility that is compatible with our results is that HTLV-I can be acquired in non-endemic countries, in which case the period between infection and disease may be shorter, there should be no difference in HTLV-I seropositivity between relatives resident in Britain and those resident in Jamaica, and the disease should occur in British born people.

A prolonged virus incubation period before seroconversion might explain the negative serology in the British born offspring as well as the increase of HTLVI seroprevalence with age. But the negative results of the polymerase chain reaction on peripheral blood DNA do not support this hypothesis, although infection of non-circulating cells such as endothelial or fibroblastic cells cannot be excluded. In vitro studies have shown that these and other non-lymphoid cells can be infected with cell free virus. ${ }^{20-22}$

The absence of HTLV-I antibodies in the 14 British born relatives, all of whom had mothers infected with HTLV-I and were breast fed, argues against maternal transmission as the main route of infection. The route of transmission in the seropositive relatives remains uncertain. Blood transfusion can be eliminated as none of the subjects had had one, though all relatives reported having been breast fed. Japanese and preliminary Caribbean studies show rates of $15-20 \%$ for mother to infant transmission, ${ }^{13} 1+23$ which may also be due to exchange of uteroplacental blood perinatally or other forms of direct blood transfer during birth. Hino et al found that cord blood of seropositive mothers contained IgG antibody, the concentration of which diminished rapidly after birth, and did not find $\operatorname{Ig} M$ antibodies (of infant origin) or infected lymphocytes. ${ }^{24}$ Lymphocytes infected with the virus have been detected by immunofluorescence in human breast milk, and transmission through suckling has been shown in animals. ${ }^{24-26}$ Yet studies have reported that $75-80 \%$ or more of infants born to seropositive mothers do not seroconvert in their first three years of life. Seroconversion then levels off until beyond the age of 15 years or so. ${ }^{13}$ Such a plateau throughout childhood has been reported by both Jamaican ${ }^{10}$ and Japanese studies $^{27}$ and is consistent with infection being transmitted from sources other than from the mother-for example, through sexual activity. The negative results in the 14 offspring born in Britain in this study are compatible with relatively inefficient rates of mother to infant transmission because the small numbers have wide confidence intervals. It would be premature to prevent seropositive mothers from breast feeding, particularly in areas of low prevalence of HTLV-I where lifetime disease risks remain low. It has not been confirmed that breast milk was the source of infection in any case of disease; other advantages of breast feeding, particularly in developing countries, currently outweigh the risks.

Sexual transmission (most efficiently from men to women) is generally thought to be the main method of HTLV-I transmission in adults. ${ }^{28}$ Infectivity by this route seems to be low judging from the slow rate of seroconversion in wives of infected men $^{14}$ and from the low rate of infection with HTLV-I in promiscuous homosexuals whose partners are infected..$^{24}$ It may not be an adequate explanation for the significant difference in seroprevalence in this study between Jamaican born children (4/9) compared with British born offspring $(0 /$ 
14). Rather some factors related to place of birth and early residence, perhaps close cohabitation in poor housing with an index patient, seem to promote HTLV-I infection. Improvement in such conditions was a prime reason for migration; indeed in 1897 the first Jamaican account of a tropical spastic paraparesislike syndrome reported that many cases were found among the poor, as was found later. ${ }^{31} 32$

In conclusion, our data suggest that place of birth and early residence rather than maternal or age effects are the important factors in HTLV-I infection. No evidence of prolonged seronegative incubation of HTLV-I has been found.

We thank the Multiple Sclerosis Society of Great Britain and Northern Ireland for JHR's research fellowship and for supporting this study. JKC received support from the Wellcome Trust.

1 Yoshida M, Miyoshi I, Hinuma Y. Isolation and characterisation of retrovirus from cell lines of human adult $T$-cell leukaemia and its implication in the from cell lines of human adult T-cell leukaemia
disease. Proc Natl Acad Sci USA 1982;79:2031-5.

2 Anonymous. HTLV-1 comes of age [Editorial]. Lancet 1988;i:217-9.

3 Rodgers-Johnson P, Morgan OC, Mora C, et al. The role of HTLV-1 in tropical spastic paraparesis in Jamaica. Ann Neurol 1988;23:121-6.

4 Morgan OC, Montgomery RD, Rodgers-Johnson P. The myelopathies of Jamaica: an unfolding story. $Q \mathcal{F}$ Med 1988;67:273-82.

Catovsky D, Greaves MF, Rose M, et al. Adult T-cell lymphoma-leukaemia in blacks from the West Indies. Lancet 1982;i:639-43.

6 Blattner WA, Nomura A, Clark JW, et al. Modes of transmission and evidence for viral latency from studies of HTLV-I in Japanese migrant populations in Hawaii. Proc Natl Acad Sci USA 1986;83:4895-8.

7 Newton $M$, Cruickshank JK, Miller D, et al. Antibody to human T lymphotropic virus type $I$ in West Indian born UK residents with spastic pamphotropic virus type 1 in

8 Cruickshank JK, Rudge P, Dalgleish AG, et al. Tropical spastic paraparesis and HTLV-1 in the United Kingdom. Brain 1989;112:1057-90.

9 Tokudome S, Tokunaga $\mathrm{O}$, Shimamoto $\mathrm{Y}$, et al. Incidence of adult T-cell leukaemia/lymphoma among HTLV-1 carriers in Saga, Japan. Cancer Res 1989;49:226-8.

10 Murphy EL, Hanchard B, Figueroa JP, et al. Modelling the risk of adult T-cell leukaemia/lymphoma in persons infected with HTLV-1. Int $\mathcal{J}$ Cancer 1989;43:250-3.

11 Kondo T, Kono H, Miyamoto N, et al. Age and sex-specific cumulative rate and risk of ATLL for HTLV-1 carriers. Int 7 Cancer 1989;43:1061-4.

12 Inaba S, Sato H, Okochi K, et al. Prevention of transmission of HTLV-1 through transfusion, by donor screening with antibody to the virus. Transfusion 1989;7:1-11.

13 Kusuhara K, Sonoda S, Takahashi K, et al. Mother-to-child transmission of
HTLV-1: a fifteen-year follow-up study in Okinawa, Japan. Int $\mathcal{F}$ Cancer 1987;40:755-7.

4 Ka)iyama W, Kashiwagi S, Ikematsu $\mathrm{H}$, et al. Intrafamilial transmission of adult T-cell leukaemia virus. I Infect Dis 1986;154:851-7.

15 Miller GJ, Pegram SM, Kirkwood BR, et al. Ethnic composition, age and sex, together with location and standard of housing as determinants of HTLV 1 infection in an an

16 Marmot MG. General approaches to migrant sudies: the relions disease, sociol the relation between disease, social class and ethnic origin. In: Cruickshank JK, Beevers DG 1989.

17 Dalgleish AG, Richardson JH, Matutes E, et al. HTLV-1 infection in TSP: lymphocyte culture and serological response. AIDS and Human Retroviruses $1988: 4: 475-85$

18 Sinclair AL, Habeshaw JA, Muir L, et al. Antibody-dependent cell-mediated cytotoxicity: comparison between HTLV-1 and HIV assays. AIDS 1988;2: 465-7

19 Madisen L, Hoar DI, Holroyd CD, et al. DNA banking: the effects of storage of blood and isolated DNA on the integrity of DNA. Am F Med 1987;27 $379-90$.

19a Richardson JH, Wucherpferrig KW, Endo $\mathrm{N}$, et al. Polymerase chain reaction analysis of DNA from multiple sclerosis patients for the presence of HTLV-I. Science 1989;246:821-3.

20 Hoxie JA, Matthews DM, Clines DB. Infection of human endothelial cells by HTLV-1. Proc Natl Acad Sci USA 1984;81:7591-5.

21 Ho DD, Rota TR, Hirsh MS. Infection of human endothelial cells by HTLV-1. Proc Natl Acad Sci USA 1984;81.23:7588-90.

22 Clapham P, Nagg K, Cheingsong-Popov R, Exley M, Weiss RA. Productive infection and cell-free transmission of HTLV-1 in a non-lymphoid line. Science 1983:222:1125-7.

23 Pate EJ, Wiktor SZ, Murphy EL, et al. Maternal-infant transmission of HTLV-1 in Jamaica. West Indian Med f 1989;38 (suppl 1):34

24 Hino S, Yamaguchi K, Katamine S, et al. Mother-to-child transmission of human T-cell leukaemia virus type-1. fapanese foumal of Cancer Research (Gann) 1985;76:474-80.

25 Kinoshita K, Hino S, Amagasaki T, et al. Demonstration of adult T-cell leukaemia antigen in milk from three seropositive mothers. Fapanese fournal of Cancer Res (Gann) 1984;75:103-5.

26 Hirose S, Kotani S, Uemura Y, et al. Milk-borne transmission of human Tcell leukaemia virus type 1 in rabbits. Virology 1988;162:487-9.

27 Tajima K, Kamura S, Ito $M$, et al. Epidemiological features of HTLV- 1 carriers and incidence of ATL in an ATL-endemic island: a repor of the community-based co-operative study in Tsushima, Japan. Int $\mathcal{Y}$ Cancer 1987;40:741-6.

28 Murphy EL, Figueroa JP, Gibbs WN, et al. Sexual transmission of HTLV-1. Ann Intern Med 1989;111:555-60.

29 Tedder RS, Shauson DC, Jeffries DJ, et al. Low prevalence in the UK of HTLV-1 and HTLV-2 infection in subjects with extended lymphadenoHTLV-1 and HTLV-2 infection in subjects with
pathy and at risk of AIDS. Lancet 1984;ii:125-8.

30 Strachan H. On a form of multiple neuritis in Jamaica. Practitioner 1897;59. 477-8

31 Cruickshank EK. A neuropathic syndrome of uncertain origin: review of 100 cases. West Indian Med $\mathcal{F}$ 1956;5:147-58.

32 Montgomery RD, Cruickshank EK, Robertson WB, McMenemey WH. Clinical and pathological observations on Jamaican neuropathy: a report on 206 cases. Brain 1964;87:425-62.

(Accepted 27 November 1989)

\section{Absorption of glycine irrigating solution during transcervical resection of endometrium}

\section{Ralf Baumann, Adam L Magos, Jonathan D S Kay, Alexander C Turnbull}

Nuffield Department of Obstetrics and

Gynaecology, University of Oxford, John Radcliffe

Hospital, Oxford OX3 9DU

Ralf Baumann, MD, research

fellow in gynaecological

endoscopy

Adam L Magos, MRCOG, clinical lecturer

Sir Alexander C Turnbull,

FRCOG, professor

Nuffield Department of

Clinical Biochemistry,

University of Oxford, John

Radcliffe Hospital

Jonathan D S Kay,

MRCPATH, consultant

chemical pathologist

Correspondence to: $\mathrm{Mr}$

Magos.

BrMed f 1990;300:304-5
We recently described transcervical resection of the endometrium as a less invasive alternative to hysterectomy for menorrhagia.' The operation is similar to transurethral resection of the prostate in terms of technique and the use of liquid media such as $1.5 \%$ glycine solution for distension and irrigation. As absorption of large volumes of such fluid can cause fluid overload, hyponatraemia, cerebral oedema, haemolysis, and even death ${ }^{2}$ we assessed the risk of these complications associated with the operation.

\section{Patients, methods, and results}

We studied 10 women aged 34-51 who were undergoing endometrial resection for symptoms of menorrhagia. They were otherwise healthy, and none took drugs that affected renal function. All women were starved for six hours preoperatively, and intravenous fluids were not used during the operation. The operative technique was as described previously ${ }^{1}$ and included careful monitoring of inflow and outflow of the uterine irrigant. Haemoglobin concentration, packed cell volume, plasma osmolality, lactate dehydrogenase activity (an indicator of haemolysis), and plasma concentrations of sodium, potassium, creatinine, total protein, albumin, and glycine were measured before, during (at 10, 20, and 30 minutes), and after (at two, four, six, and 24 hours) resection.

The mean operating time was $39 \cdot 2$ minutes (range 20-80). Vital signs remained normal in all cases, and the mean estimated blood loss was $133 \mathrm{ml}(80-200)$. A mean of $4948 \mathrm{ml}$ irrigant was infused into the uterus (1750-8900), the mean deficit of fluid at the end of the operation being $643 \mathrm{ml}(100-2030)$. The volume of fluid absorbed was smallest $(100$ and $200 \mathrm{ml})$ in two patients who had been sterilised.

There was a negative linear correlation between the volume of irrigant absorbed and the change in plasma sodium concentration $(\mathrm{r}=-0.717, \mathrm{p}<0.02)$; hyponatraemia of 125 and $130 \mathrm{mmol} / \mathrm{l}$ occurred in two women within 10-30 minutes of the start of the operation, both women having absorbed more than $900 \mathrm{ml}$ of irrigant. Changes in plasma sodium concentration were paralleled by falls in total protein, albumin, and haemoglobin concentrations and packed cell volume, but only minor fluctuations occurred in potassium and creatinine concentrations (table). Lactate dehydrogenase activity increased after the operation in the two women with hyponatraemia. Only two out of nine women monitored showed an increase 